Vol. 2 No.1, 1 April 2017

\title{
ANALISIS SEMIOTIK DALAM KUMPULAN CERPEN AIR MATA IBUKU DALAM SEMANGKUK SUP AYAM
}

\author{
Lili Agustina \\ Program Studi Pendidikan Bahasa dan Sastra Indonesia \\ STKIP PGRI Banjarmasin \\ Email: lili.agustina@ stkipbjm.ac.id
}

\begin{abstract}
Abstrak
Karya sastra dalam kajian semiotika menitikberatkan pada sistem tandatanda atau kumpulan tanda-tanda. Sebuah karya sastra dapat menyajikan tandatanda yang dapat dilihat dari pemakaian bahasa yang digunakan. Tanda-tanda yang ada pada karya sastra harus diungkap untuk mengetahui pesan yang ingin disampaikan oleh pengarang. Dengan semiotik, pembaca dapat menangkap pesan atau maksud dari cerpen yang berjudul "Air Mata Ibuku dalam Semangkuk Sup Ayam" yang tidak ditampilkan pengarang secara jelas. Pada saat membaca, seseorang akan menginterpretasikan dengan cara yang berbeda berdasarkan pemahaman pembaca tersebut. Namun, semua itu dapat dibatasi oleh adanya pemahaman dalam konvensi bahasa, sastra, dan budaya.

Pendekatan yang digunakan dalam penelitian ini adalah pendekatan semiotik, yaitu membahas tanda-tanda dalam cerpen yang berjudul "Air Mata Ibuku dalam Semangkuk Sup Ayam". Metode penelitian yang digunakan kualitatif deskriptif. Data yang terkumpul diklasifikasikan atau dikelompok-kelompokan menurut jenis, sifat, atau kondisinya, setelah datanya lengkap, kemudian dibuat kesimpulan.

Sebuah karya sastra dapat menyajikan tanda-tanda yang dapat dilihat dari pemakaian bahasa yang digunakan.Bertolak dari pandangan bahwa semua yang terdapat dalam karya sastra merupakan lambang-lambang atau kode-kode yang mempunyai arti/makna tertentu. Arti/makna tertentu di sini berkaitan erat dengan sistem masyarakat. Berdasarkan hasil penelitian, ditemukan dalam cerpen ini terdapat beberapa kode, yaitu kode teka-teki, simbolis, aksian, dan budaya untuk membantu menginterpretasikan cerpen yang berjudul "Air Mata Ibuku dalam Semangkuk Sup Ayam".
\end{abstract}

Kata kunci: cerpen dan semiotik

\section{PENDAHULUAN}

Sastra adalah suatu seni yang menggunakan bahasa sebagai mediumnya. Sastra pada prinsipnya adalah karya imajinatif sebagai cerminan realitas kehidupan manusia dengan lingkungannya dan bentuk pengungkapan bahasa yang bersifat artistik. Secara teoritis tanpa bahasa sastra tidak mungkin ada. Sastra lisan dan sastra tulisan terwujud karena dengan adanya bahasa. 
Sastra adalah salah satu kebudayaan atau ciri khas yang dimiliki seseorang dalam suatu daerah tertentu. Sastra merupakan salah salah satu kebudayaan manusia dan juga membudayakan manusia itu sendiri. Sastra adalah bagian dari hidup manusia. Seperti yang dikemukakan Semi (dalam Jamaludin, 2003:31) mendefinisikan sastra adalah suatu bentuk atau hasil pekerjaan seni kreatif yang objeknya adalah manusia dan kehidupannya, dengan menggunakan bahasa sebagai mediumnya. Sastra menggunakan bahasa yang memiliki nilai estetika atau keindahan di dalamnya. Sastra pada prinsipnya adalah sebuah karya imajinatif yang merupakan refleksi dan realitas dari kehidupan si penulis berdasarkan apa yang dilihat dan dirasakan di lingkungannya.

Karya sastra memiliki misi untuk pembaca agar dapat belajar. Hal ini serupa seperti yang dikemukakan oleh Rusyana (dalam Effendi dan Sabhan, 2007:6) bahwa pada hakikatnya sastra tradisional tercipta dan dicipta dengan tujuan tertentu yang menurutnya tujuan itu antara lain untuk memberikan pelajaran, penjelasan atau hiburan. Dengan tujuan itu, sebuah karya sastra sarat dengan nilai-nilai kehidupan. Nilai sastra dalam kehidupan di masyarakat erat kaitannya dengan fungsi sosial sastra.

\section{KAJIAN PUSTAKA \\ Pendekatan Semiotik}

Istilah semiotik berasal dari kata Yunani Kuno, yaitu "semeion" yang berarti tanda atau dalam bahasa Inggris, yaitu“sign". Semiotik merupakan ilmu yang mengkaji tentang tanda-tanda. Ilmu ini menganggap bahwa fenomena sosial atau masyarakat dan kebudayaan di dalamnya merupakan tanda-tanda. Semiotik juga mempelajari sistem-sistem, aturan-aturan yang memungkinkan tanda-tanda tersebut mempunyai arti.

Tokoh dalam semiotik ini yang terkenal ada dua orang, yaitu seorang ahli linguistik yang bernama Ferdinand de Saussure (1857-1913) dan seorang filsafat yang bernama Charles Sander Peirce (1939-1914). Pada saat itu, Saussure menyebut semiotik dengan ilmu semiologi dan Pierce menyebutnya semiotik (semiotics). Seperti yang dikemukakan oleh Peirce semiotika didasarkan pada logika, yaitu bagaimana orang bernalar. Penalaran tersebut dapat dilihat dari tanda-tanda. Kemudian, pada akhirnya kedua nama ini sering dipergunakan secara berganti-ganti dengan pengertian yang sama.

Semiotika dapat dijadikan sebuah pendekatan dalam melakukan analisis karya sastra. Seperti yang kita ketahui sebuah karya sastra dapat menyajikan tanda-tanda yang dapat dilihat dari pemakaian bahasa yang digunakan. Pada saat membaca, seseorang akan menginterpretasikan dengan cara yang berbeda berdasarkan pemahaman pembaca tersebut. Namun, semua itu dapat dibatasi oleh adanya pemahaman dalam konvensi bahasa, sastra, dan budaya.

Seperti yang dikemukakan oleh Barthes (dalam Tarsyad, Tanpa tahun:6) ada lima sistem kode dalam kajian semiotik, yaitu 1) kode teka-teki, 2) kode konotatif, 3) kode simbolis, 4) kode aksian, dan 5) kode budaya.

1. Kode teka-teki berkisar pada harapan pembaca mendapatkan nilai kebenaran terhadap pertanyaan-pertanyaan yang muncul dalam karya sastra. Dalam narasi tradisional kode ini menjadi struktur utama. 
Vol. 2 No.1, 1 April 2017

2. Kode konotatif merupakan kode yang menawarkan pembaca untuk menyusun tema pada saat pembacaan. Konotasi kata frasa dapat dikelompok menjadi konotasi kata frasa yang mirip.

3. Kode simbolis merukan lambang atau dunia perumpamaan dalam menghayati arti hidup dan kehidupan. Simbol merupakan aspek pengodean fiksi yang paling khas bersifat struktural.

4. Kode aksian merupakan kode perbuatan-perbuatan atau aktivitas yang dituangkan dengan bahasa yang disusun secara linear. Semua aksian dapat dikodifikasi dari awal sampai akhir

5. Kode budaya merupakan acuan teks kepada benda-benda yang sidah diketahui dan dikodifikasi oleh budaya. Kode ini memiliki hubungan atau pengkajian dengan masyarakat. faktor yang dikaji adalah bahasa dan nonbahasa. Dalam hal ini, keterkaitan dengan realitas budaya di masyarakat.

\section{METODE}

Penelitian deskriptif pada umumnya dilakukan dengan tujuan utama, yaitu menggambarkan secara sistematis fakta dan karakteristik objek dan subjek yang diteliti secara tepat. Penelitian deskriptif menurut Arikunto (2010:3), adalah penelitian yang benar-benar hanya memaparkan apa yang terjadi dalam sebuah kancah lapangan atau wilayah tertentu. Data yang terkumpul diklasifikasikan atau dikelompok-kelompokan menurut jenis, sifat, atau kondisinya, setelah datanya lengkap, kemudian dibuat kesimpulan. Dalam penelitian ini peneliti berperan sebagai instrumen utama. Peneliti dalam hal ini sebagai instrumen utama karena memegang kendali dalam proses pengumpulan data, pendeskripsikan data, penganalisis data, serta penarik simpulan dari hasil penelitian.

Pendekatan yang digunakan dalam penelitian ini adalah pendekatan semiotik Pendekatan semiotik adalah pendekatan yang bertolak dari pandangan bahwa semua yang terdapat dalam karya sastra merupakan lambang-lambang atau kode-kode yang mempunyai arti/makna tertentu. Arti/makna tertentu di sini berkaitan erat dengan sistem masyarakat. Pengetahuan yang dianut tidak akan pernah dilepaskan dalam menganalisis dengan menggunakan pendekatan semiotik. Semiotika dapat dijadikan sebuah pendekatan dalam melakukan analisis karya sastra. Seperti yang kita ketahui sebuah karya sastra dapat menyajikan tanda-tanda yang dapat dilihat dari pemakaian bahasa yang digunakan.

\section{Pembahahasan}

\section{Kode Teka-teki Cerpen "Air Mata Ibuku dalam Semangkuk Sup A yam"}

Kode teka-teki berkisar pada harapan pembaca mendapatkan nilai kebenaran terhadap pertanyaan-pertanyaan yang muncul dalam karya sastra. Dalam narasi tradisional, kode ini menjadi struktur utama. Ada suatu kesinambungan antara pemunculan suatu peristiwa berteka-teki dan penyelesainnya dalam cerita. Kode ini membangkitkat hasrat dan kemauan untuk menemukan jawaban ataspertanyaan yang dikandungsebuah karya prosa fiksi.

Kode teka-teki cerpen "Air Mata Ibuku dalam Semangkuk Sup" dalam kumpulan cerpen karya Marisa Tracy adalah terdapat sebuah teka-teki yang mana 
cerpen ini menceritakan seorang ibu yang bersedih telah kehilangan anaknnya dan tidah tahu anaknnya tersebut berada di mana. Hal ini dapat terlihat pada penggalan cerpen di bawah ini.

Penculik sialan! Gara-gara dia aku nggak bisa melihat Melisa. Melisa yang seharusnya berada di sisiku sekarang. Melisa yang seharusnya sudah mulai bertumbuh menjadi anak yang pintar dan cantik. Kamu di mana, Nak? Hati miranti semakin teriris dan pedih. Kejadian beberapa tahun silam masih terus terkenang, dan tak akan pernah terlupa. Sampai sekarang.

Bagaimana tidak, penculik yang hingga kini masih misterius itu telah menculik anak perempuannya yang dulu masih berusia dua tahun di sebiah mal. Polisi tidak mampu melacak jejak sang biadab itu. Miranti kecewa. Sungguh kecewa pada semmua orang, termasuk dirinya sendiri yang ia anggap tidak mampu menjaga puterinya dengan baik. Nuraninya mengatakan bahwa dagingnya itu masih hidup.

Cerpen tersebut tidak mengatakan dengan sebenarnya bagaimana keadaan anak tokohdalam cerpen tersebut. Tokoh itu bernama Miranti. Pada cerita tersebut juga terdapat teka-teki yang membuat pembaca bertanya-tanya, siapakah anak gembel yang ada di restoran itu. Hal tersebut dapat dilihat pda penggalan cerpen di bawah ini.

Seorang gadis kecil berusia sekitar sepuluh tahun datang menghampiri si pelayan restoran.Gadis gembel itu menadahkan tangan kanan sebagai ungkapan permintaan. "Kak, aku boleh minta supnya?"

Pelayan itu iba melihat gadis kecil yang sepertinya begitu kelaparan. Badannya kurus, mukanya kusam, dan baju yang dikenakan tidak layak pakai. Ada robekan dimana-mana Gadis pelayan tersenyum, dan berkata ramah.

"Tunggu sebentar, ya. Kakak pindahkan keplastik dulu. Jadi, kamu bisa bawa pulang."

"Hei, kamu!" Panggil seorang satpam restoran dengan suara galak."Lagilagi kamu, Gembel!"

"Ampun Pak, ampun! Saya belum makan dari kemarin.Saya Cuma minta makanan bekas," ujar bocah perempuan itu sambil menangis, dan lari bersembunyi dibalik tubuh pelayan baik hati.

"Sudah, Pak. Nggak apa-apa. Benar, pak. Anak ini nggak macammacam, kok. Saya Cuma mau ngasih dia makanan bekas ini. Punya salah satu pelanggan kita tadi yang tidak termakan habis. Sayang kalau dibuang," ungkap pelayan itu.

Sampai cerita selesai tidak pernah ditemukan siapa anak gembel yang ada di restoran itu sebenarnya. Apakah ada hubungannya dengan Miranti, dan apakah anak itu merupakan anak Miranti.

Satpam berhasil diberi pengertian. Tampaknya sup ayam itu berjodoh dengan si gadis kecil yang malang. Setidaknya hari ini ia 
bersyukur bisa mendapatkan sedikit makanan untuk mengganjal perut. Dan, mungkin merasakan hangatnya masakan seorang bunda yang tidak pernah didapatnya lagi sejak tinggal bersama"Keluarga baru"-nya disalah satu wilayah kumuh di kota. Ya, dulu. Dulu sekali. Ketika pijar kenangan yang sudah mulai memudar dari otak kecil menyeretnya ke sederetan perumahan mewah nun jauh di ujung sana.

\section{Kode K onotatif Cerpen "Air M ata I buku dalam semangkuk Sup Ayam"}

Kode konotatif menawarkan banyak sisi dalam sastra. Pembaca menyusun tema pda saat pembacaan. Konotasi katafrasa tertentu dalam frasa oleh pembaca dapat dikelompokan dengan konotasi kataatau frasa yang mirip. Dalam prosafiksi, tanda-tanda verbal yang digunakan menemukan keutuhannya.kumpulan satuan konotasi mengantarkan kepada pembaca tema cerita yang bersangkutan.

Berdasarkan penjelasan tersebut, kode konotatif yan terdapatpada cerpen "Air Mata Ibuku dalam Semangkuk Sup Ayam" terutama mengenai tokoh Miranti atau Ibu Melisa yang senantiasa menyesali perbuatanya karena tidak menjaga anaknnya dengan benar. Melisa diculik oleh seseorang yang misterius, samapa isekarang Miranti belum dapat menemukan anaknnya, yang kini entah berada di mana, apakah dia masih hidup.

Dia pun akhirnya singgah sendirian di sebuah restoran. Setelah menu makanan dia tertarikdengan sup ayam. Sambil mengingat kejadian yang telah menculik anaknnya itu, Miranti menangis. Sup ayan yang yang telah ada di meja tidak jadi dimakannya. Air matanya jatuh di dalam sup ayam tersebut. Kesedihan dan rasa bersalah Miranti dapat dilihat pada penggalan cerpen berikut.

Miranti pergi sendiri dan duduk termenung di sebuah meja restoran. Tidak seperti biasanya ia pergi sendiri. Apalagi hanya untuk makan di restoran. Sangat tidak etis baginya kalau ke mana-mana harus sendirian. Maya anak perempuan semata wayangnya yang masih berusia enam tahun, atau salah satu teman karibnya.

... .

Miranti buru-buru menghapus air matanya."Oh, iya. Terima kasih." Ia bisa mengurut dada. Setidaknya gadis pelayan itu tidak menanyakan mengapa ia hamper menangis.

Baru saja ia berniat memasukkan sesendok kuah dan irisan wortel kedalam mulutnya selagi sup masih hangat, namun terasa begitu berat. Dikembalikannya lagi sendok itu. Bukan karena perutnya kenyang, tetapi karena hatinya sendiri yang sedang gundah. Air mata keluar lagi dan tetesannya terjatuh kedalam mangkuk sup itu. 
Vol. 2 No.1, 1 April 2017

Sementara itu, kekecewaan Miranti, gara-gara tidak pernah lagi melihat anaknnya, Melisa, dapat dilihat pada pengalan cerpen di bawah ini.

Penculik sialan! Gara-gara dia aku nggak bisa melihat Melisa. Melisa yang seharusnya berada di sisiku sekarang. Melisa yang seharusnya sudah mulai bertumbuh menjadi anak yang pintar dan cantik. Kamu di mana, Nak? Hati miranti semakin teriris dan pedih. Kejadian beberapa tahun silam masih terus terkenang, dan tak akan pernah terlupa. Sampai sekarang.

Bagaimana tidak, penculik yang hingga kini masih misterius itu telah menculik anak perempuannya yang dulu masih berusia dua tahun di sebiah mal. Polisi tidak mampu melacak jejak sang biadab itu. Miranti kecewa. Sungguh kecewa pada semmua orang, termasuk dirinya sendiri yang ia anggap tidak mampu menjaga puterinya dengan baik. Nuraninya mengatakan bahwa dagingnya itu masih hidup.

Miranti selalu berharap, Melisa anaknnya masih hidup. Pengharapan Miranti dapatdilihat pada kutipan cerpen di bawah ini.

Miranti membayangkan kalau saja Melisa kini ada di sisnya, mungkin darah dagingnya itu yang akan memakan sup itu. Lalu, mengapa saat ini hatinya bisa merasakan kedekatan dengan Melisa? Rasa kangen itu mulai mendera kembali. Ditinggalkannya selembar uang lima puluh ribu dibawah gelas berisi air putih sebagai tanda pembayaran. Dengan masih menundukkan kepala. Miranti meninggalkan tempat itu.

\section{Kode Simbolis Cerpen "Air M ata I buku dalam Semangkuk Sup Ayam"}

Kode simbolis adalah dunia lambang, yaitu dunia personifikasi manusia dalam menghayati arti hidup dan kehidupan. Simbol merupakan aspek pengkodean fiksi yang paling khasbersifat structural. Pengenalan symbol dilakukan melalui kelompok-kelompok bentuk yang teratur, mengulangi bermacam kode dan maksud dalam teks.

Kode simbolis pada cerpen "Air Mata Ibuku dalam Semangkuk Sup Ayam" terutama mengenai tokoh Miranti dan semangkuk sup.semangkuk sup ayam inilah yang membuat Miranti mengingatmasa lalu dengan ibunya yang telah meninggalkannya. Semangkuk sup ayamitu sudah dingin dan di sup ayam tersebut ada air mata ibunya yang sedang menangis atas kesalahan Miranti sewaktu kecil.

Melihat air matanya jatuh di dalam sup, mendadak Miranti teringat akan sang bunda yang telah meninggalkannya selamanya tujuh tahun silam. Otak kecil membawanya kembali ke masa kecilnya. Masa yang ia anggap biasa dan tidak ada istimewanya sama sekali, namun hanya satu yang ai anggap berharga, yaitu sang bunda. Persis sekali seperti saat ini ketika ia melihat air matanya jatuh ke dalam permukaan sup, begitu pula ibunya melakukan hal yang sama dengan sup ayam hangat yang dibuat oleh tangannya sendiri. Bukan karena kesengajaan, namun saat itu sang 
Vol. 2 No.1, 1 April 2017

bunda sedang dalam keadaan emosi. Emosi lantaran Miranti membuat kesalahan besar dan menyebabkan ibunya menanngis sesenggukan sehingga air matanya terjatuh di dalam sup ayam yang dibuatnya untuk Miranti.

Entah kesalahan besar apa yang dibuatnya, Miranti sudah lupa. Hanya kejadian yang berhubungan dengan sup ayam itu yang diingatnya. Sup ayam itu menjadi dingin. Bunda meninggalkannya sambil tetap dalam keadaan menangis. Miranti kecil menyesal dan meratapi kesalahannya sendiri. Diraihnya sup ayam itu dan dihabiskannya walaupun sudah dingin dan bercampur air matasang bunda. Ketika melahap sup itu, ia bisa merasakan pengorbanan ibunya yang begitu besar. Tangisannya semakin deras meskipun ia sudah berusaha sekuat tenaga menahan.

Kode simbolis yaitu semangkuk sup ayam jug membuat pembaca bertanya-tanya. Siapakah yang memakan sup ayam tersebutdi restoran. Sup ayam tersebut sudah dingin. Di dalam sup ayam tersebut terdapat air mata Miranti yang saat itu sedang menangis.

Seorang gadis kecil berusia sekitar sepuluh tahun datang menghampiri si pelayan restoran.Gadis gembel itu menadahkan tangan kanan sebagai ungkapan permintaan. "Kak, aku boleh minta supnya?"

Pelayan itu iba melihat gadis kecil yang sepertinya begitu kelaparan. Badannya kurus, mukanya kusam, dan baju yang dikenakan tidak layak pakai. Ada robekan dimana-mana Gadis pelayan tersenyum, dan berkata ramah.

“ Tunggu sebentar, ya. Kakak pindahkan keplastik dulu. Jadi, kamu bisa bawa pulang."

\section{Kode A ksian Cerpen "Air M ata I bukudalam Semangkuk Sup A yam"}

Kode aksian mengandungprinsip bahwa perbuatan yang dituangkan dengan bahasa harus disusun secara lancar. Kode adalah pelengkapan utama teks yang dibaca orang. Semua aksian dapat dikodifikasi dari awal sampai akhir. Dasar penuangan secara linear itu adalah karena tidak semua aksian dapat dituangkan secara serentak dalam teks.

Ada beberapa aksian atau tindakan yang terdapat pada cerpen Air Mata Ibuku dalam Semangkuk Sup Ayam." Aksian itu ada yang bersifataktif dan ada juga akasian yang bersifatpasif. Aksian yang bersifat aktif dan dinamis sesuai dengan alur cerita pertama Miranti pergi ke sebuah restoran. Hal ini tampak terlihat paga penggalan cerpen di bawah ini.

Miranti pergi sendiri dan duduk termenung di sebuah meja restoran. Tidak seperti biasanya ia pergi sendiri. Apalagi hanya untuk 
makan di restoran. Sangat tidak etis baginya kalau ke mana-mana harus sendirian. Maya anak perempuan semata wayangnya yang masih berusia enam tahun, atau salah satu teman karibnya.

Dilihatnya daftar menu, dan ia bingung hendak memesan apa.dibilang lapar juga tidak. Entah setan apa yang membuatnya refleks memasuki restoran itu. Setelah membaca daftar menu bolak-balik, tidak ada satu pun yang membuatnya tertarik. Sup ayam? Ah, sepertinya aku butuh itu untuk menghangatkkan diri. Begitu batinnya meminta.

Aksian yang bersifat aktif dan dinamis berikutnya yaitu Miranti berusaha menutupi wajahnya dari tangisannya selama duduk di bangku restoran itu.

Tangisan tanpa suara itu terus berlanjut dan air matanya turut memenuhi isi mangkuk sup. Miranti terus menutupi wajahnya agar tidak ada satu pun orang yang melihat. Pandangannya hanya mengarah pada semangkuksup ayam itu

Pada cerpen ini terdapat aksian yang bersifat pasif dan statis yang dijumpai pada beberapa penggalan cerpen.Halini dapat terlihat pada penggalan cerpen di bawah ini.

Sembari menunggu pesanaan dating, Miranti melanjutkan kebeningan itu lagi. Ponsel di dalam tasnya bergetar. Ada panggilan dari yudi suaminya, nammun tidak diacuhkannya.

Baru saja ia berniat memasukkan sesendok kuah dan irisan wortel kedalam mulutnya selagi sup masih hangat, namun terasa begitu berat. Dikembalikannya lagi sendok itu. Bukan karena perutnya kenyang, tetapi karena hatinya sendiri yang sedang gundah. Air mata keluar lagi dan tetesannya terjatuh kedalam mangkuk sup itu.

Aksian pasif juga terdapat pada penggalan cerpen yang merupakan perasaan Miranti, pada kejadian silam,yang mana anaknnya diculik oleh seseorang yang misterius.

Penculik sialan! Gara-gara dia aku nggak bisa melihat Melisa. Melisa yang seharusnya berada di sisiku sekarang. Melisa yang seharusnya sudah mulai bertumbuh menjadi anak yang pintar dan cantik. Kamu di mana, Nak? Hati miranti semakin teriris dan pedih. Kejadian beberapa tahun silam masih terus terkenang, dan tak akan pernah terlupa. Sampai sekarang.

Mama, aku kangen sama mama. Aku nggak kuat menghadapi ini tanpa mama. Dadanya terasa sesak karena batinnya terus menjerit. 
Aksian pasif dan statis juga terdapat pada penggalan cerpen. Misalnya Miranti membanyangkan anaknya yang telah lama hilang.

Miranti membayangkan kalau saja Melisa kini ada di sisnya, mungkin darah dagingnya itu yang akan memakan sup itu. Lalu, mengapa saat ini hatinya bisa merasakan kedekatan dengan Melisa? Rasa kangen itu mulai mendera kembali.

\section{Kode Budaya Cerpen "Air M ata Ibuku dalam Semangkuk Sup A yam"}

Kode budaya merupakan acuan teks kepada benda-benda yang sudah diketahui dan dikodifikasi oleh budaya. Kodeini merupakan peran metalingual, yakni pengkajian yang dilakukan dalam masyarakatmengenai hubungan faktor bahasa dan nonbahasa. Metalingual tampak bila dihubungkan kejadian dalam teks denganrealitas budaya.

Kode budaya pada cerpen "Air Mata Ibuku dalamSemagkuk Sup Ayam" terutama berkaitan dengan kasih sayang seorang ibu yang tidak pernah hentihentinya.

Baru saja ia berniat memasukkan sesendok kuah dan irisan wortel kedalam mulutnya selagi sup masih hangat, namun terasa begitu berat. Dikembalikannya lagi sendok itu. Bukan karena perutnya kenyang, tetapi karena hatinya sendiri yang sedang gundah. Air mata keluar lagi dan tetesannya terjatuh kedalam mangkuk sup itu.

Penculik sialan! Gara-gara dia aku nggak bisa melihat Melisa. Melisa yang seharusnya berada di sisiku sekarang. Melisa yang seharusnya sudah mulai bertumbuh menjadi anak yang pintar dan cantik. Kamu di mana, Nak? Hati miranti semakin teriris dan pedih. Kejadian beberapa tahun silam masih terus terkenang, dan tak akan pernah terlupa. Sampai sekarang.

\section{PENUTUP}

\section{Simpulan}

Ada beberapa kode teka-teki yang terdapat pada cerpen "Air Mata Ibuku dalam Semangkuk Sup Ayam" karya Mariska Tracy. Pertama cerpen ini menceritakan seorang ibu yang bersedih telah kehilangan anaknnya dan tidah tahu anaknnya tersebut berada di mana. Cerpen tersebut tidak mengatakan dengan sebenarnya bagaimana keadaan anak tokohdalam cerpen tersebut. Kedua Sampai cerita selesai tidak pernah ditemukan siapa anak gembel yang ada di restoran itu sebenarnya. Apakah ada hubungannya dengan Miranti, dan apakah anak itu merupakan anak Miranti? 
Kode konotatif yan terdapatpada cerpen "Air Mata Ibuku dalam Semangkuk Sup Ayam" terutama mengenai tokoh Miranti atau Ibu Melisa yang senantiasa menyesali perbuatanya karena tidak menjaga anaknnya dengan benar. Melisa diculik oleh seseorang yang misterius, sampai sekarang Miranti belum dapat menemukan anaknnya, yang kini entah berada di mana,apakah dia masih hidup. Kekecewaan Miranti, gara-gara tidak pernah lagi melihat anaknya, Melisa. Miranti selalu berharap, Melisa anaknnya masih hidup, hatinya bisa merasakan kedekatan dengan Melisa? Rasa kangen itu mulai mendera kembali.

Kode simbolis pada cerpen "Air Mata Ibuku dalam Semangkuk Sup Ayam" terutama mengenai tokoh Miranti dan semangkuk sup.semangkuk sup ayam inilah yang membuat Miranti mengingatmasa lalu dengan ibunya yang telah meninggalkannya. Semangkuk sup ayamitu sudah dingin dan di sup ayam tersebut ada air mata ibunya yang sedang menangis atas kesalahan Miranti sewaktu kecil. Kode simbolis yaitu semangkuk sup ayam juga membuat pembaca bertanyatanya. Siapakah yang memakan sup ayam tersebutdi restoran. Sup ayam tersebut sudah dingin. Di dalam sup ayam tersebut terdapat air mata Miranti yang saat itu sedang menangis.

Ada beberapa kode aksian atau tindakan yang terdapat pada cerpen "Air Mata Ibuku dalam Semangkuk Sup Ayam." Aksian itu ada yang bersifataktif dan ada juga akasian yang bersifat pasif. Aksian yang bersifat aktif dan dinamis sesuai dengan alur cerita pertama Miranti pergi ke sebuah restoran. Aksian yang bersifat aktif dan dinamis berikutnya, yaitu Miranti berusaha menutupi wajahnya dari tangisannya selama duduk di bangku restoran itu. Aksian pasif juga terdapat pada penggalan cerpen yang merupakan perasaan Miranti, pada kejadian silam,yang anaknnya diculik oleh seseorang yang misterius.

Kode budaya pada cerpen "Air Mata Ibuku dalamSemagkuk Sup Ayam" terutama berkaitan dengan kasih sayang seorang ibu yang tidak pernah henti-hentinya

\section{Daftar Rujukan}

Arikunto, Suharsimi. 2010. Prosedur Penelitian suatu pendekatan Praktik. Jakarta. Rineka Cipta

Effendi, Rustam dan Sabhan. 2007. Sastra Daerah. Banjarmasin: PBS FKIP Unalam.

Jamaludin. 2003. Problematik Pembelajaran Bahasa dan Sastra. Yogyakarta: Adicita.

Semi, M. Atar. 1988. Anatomi Sastra. Bandung: Angkasa Raya

Tarsyad, Tarman Effendi. Tanpa tahun. Teori dan Kajian Semiotik. Banjarmasin: Diktat.

Tracy, Mariska. 2010. Air Mata Ibuku dalam Semangkuk Sup Ayam. Elex Media. 